\title{
ANALISIS KAWASAN RAWAN LONGSOR DAN KETERKAITANNYA TERHADAP KUALITAS TANAH DAN PENGGUNAAN LAHAN (KASUS DI KAWASAN AGRIBISNIS JUHUT KABUPATEN PANDEGLANG)
}

\section{ANALYSIS ON LANDSLIDE HAZARD AREA AND RELATED OF LAND QUALITY AND LAND USE (CASE STUDY IN JUHUT AGRIBISNIS AREA IN PANDEGLANG REGENCY)}

\author{
Hasmana Soewandita \\ Pusat Teknologi Reduksi Risiko Bencana, BPPT \\ Gedung 820 Geostech Kawasan Puspiptek Serpong, Tangerang Selatan \\ e-mail: hsoewandita@gmail.com
}

\begin{abstract}
Juhut region based on the government policy of Banten Province in 2015 is an area that will be developed as a center of agribusiness development area. Its existence is located on the slopes of the hills and at the same time as a residential area allegedly as an area prone to landslides. Agriculture cultivation activities related to soil fertility conditions that are on the belt of the volcano, making this area attracts the community to conduct agricultural cultivation activities despite being on a slope land. The aims of this study are the biophysical analysis of landslide hazard areas and their relationship to soil quality and land use patterns. The method used in this study is observation and groundceck of field biophysical condition and overlay analysis of thematic map related to landslide prone condition. The results of the study indicate that the biophysical condition of the land indicates that the landslide prone areas are susceptible to $707.1 \mathrm{Ha}(70 \%)$, while the high vulnerability area reaches $245.3 \mathrm{Ha}(24 \%)$. Soil fertility causes attractive soil to be managed by the community for the cultivation of seasonal crops or horticultural crops that can further trigger a landslide. This is also because the soil type conditions also have physical properties that are vulnerable to the early behavior of seasonal changes (from dry season to rainy season). Land use that is not suitability with morphological conditions of land and already managed by the community as an economic source will be a threat of high vulnerability to landslide hazards.
\end{abstract}

Keywords: Agribisnis Area, Land Slides Hazard, Soil Biophysical, Land Quality

\begin{abstract}
ABSTRAK
Wilayah Juhut berdasarkan kebijakan pemerintahan Propinsi Banten tahun 2015 merupakan kawasan di lereng Gunung Karang yang dikembangkan sebagai sentra pengembangan kawasan agribisnis. Keberadaannya yang terletak dikawasan berlereng dan sekaligus sebagai kawasan yang berpemukiman ditengarahi sebagai wilayah yang rawan longsor. Aktivitas budidaya pertanian terkait dengan kondisi tanahnya yang berada pada sabuk gunung berapi, membuat kawasan ini menarik masyarakat untuk melakukan aktivitas budidaya pertanian meskipun berada pada lahan berlereng. Tujuan dari kajian ini adalah melakukan analisis biofisik kawasan rawan longsor dan keterkaitannya dengan kualitas tanah dan pola penggunaan lahannya. Metoda yang digunakan dalan kajian ini adalah observasi dan groundceck kondisi biofisik lapangan serta analisis overlay peta tematik terkait kondisi daerah rawan longsor. Hasil kajian menunjukkan kondisi biofisik lahan mengindikasikan daerah rawan longsor sebagian mempunyai kelas rawan sedang sekitar $707.1 \mathrm{Ha}(70 \%)$, sedangkan kawasan rawan tinggi mencapai sekitar $245.3 \mathrm{Ha}$ (24\%). Kesuburan tanah menyebabkan tanah menarik untuk dikelola oleh masyarakat untuk usaha budidaya tanaman semusim ataupun tanaman hortikultura yang selanjutnya dapat meningkatkan dan memicu terjadinya
\end{abstract}


longsor apalagi kondisi jenis tanahnya juga mempunyai sifat fisik yang rentan terhadap perilaku awal perubahan musim (dari musim kemarau ke musim penghujan). Penggunaan lahan yang tidak sesuai dengan kondisi morfologi lahan dan telah dikelola oleh masyarakat sebagai sumber ekonomi akan menjadi ancaman kerentanan tinggi terhadap bahaya longsor.

Katakunci: Kawasan Agribisnis, Rawan Longsor, Biofisik Lahan, Kualitas Lahan

\section{PENDAHULUAN}

\subsection{Latar Belakang}

Pencanangan wilayah Juhut sebagai pengembangan kawasan agribisnis berimplikasi pada kebijakan daerah propinsi Banten terhadap kepentingan suksesnya pengembangan kawasan tersebut. Berbagai program kegiatan sebagai perwujudan sistem inovasi daerah telah dikembangkan dalam kerangka suksesnya pilot project pengembangan kawasan agisbisnis tersebut. Salah satu program kegiatan yang menunjuang kegiatan pengembangan agibisnis peternakan maupun pertanian di wilayah Juhut adalah kajian wilayah rawan longsor di wilayah Juhut Kabupaten Pandeglang. Sebagaimana diketahui wilayah Juhut berada pada wilayah bentang lahan lereng Gunung Karang. Kondisi fisiografi lahannya berombak hingga berbukit dengan penggunaan lahan sawah tadah hujan hingga hutan sekunder.

Dalam rangka untuk meningkatkan kapasitas masyarakat maupun kelembagaan pemerintah baik desa hingga kabupaten untuk pengurangan risiko bencana utama longsor, maka perlu adanya kebijakan kajian tentang wilayah rawan longsor. Sehingga masyarakat dan juga kelembagaan bisa mengetahui wilayah mana yang terindikasi mempunyai potensi paling rawan hingga wilayah yang ancaman bahaya

bencana longsornya rendah. Analisis zonasi wilayah rawan longsor di wilayah Juhut Kabupaten Pandeglang sangat dipengaruhi oleh berbagai parameter lingkungan atau biofisik lahan.

Kondisi penggunaan lahan di wilayah Juhut bervariasai dari mulai permukiman / perkampungan, sawah tadah hujan, tegalan/perladangan, kebun campuran hingga hutan. Secara faktual, aktivitas budidaya baik yang intensif hingga perkebunan/kebun campuran menjadi bagian aktivitas pengelolaan lahan bagi sebagian masyarakat Juhut. Keberadaan aktivitas budidaya pada lahan berlereng ternyata juga banyak terjadi diwilayah Juhut. Wilayah yang berlereng curam memang sebaiknya untuk kegiatan budidaya tanaman keras. Implikasi antara aktivitas budidaya dan pengelolaan lahan pada kawasan berlereng ditelusuri berdasarkan kondisi kesuburan lahannya. Apabila kesuburan lahan sangat kurang dan bahkan kritis tentunya masyarakat akan enggan melakukan aktivitas budidaya pada lahan berlereng tersebut. Sebaliknya kondisi kesuburan lahan yang baik, ada kecenderungan aktivitas budidaya juga meningkat, sehingga meskipun keterkaitan langsung dengan daerah rawan bencana longsor tidak terkait secara langsung, namun pengelolaan lahan subur yang mendukung untuk aktivitas budidaya pertanian, dapat atau akan menjadi salah satu trigger dalam kerawanan kejadian bencana longsor, terutama pada lahan yang berlereng curam setelah faktor faktor utama lainnya terpenuhi.

\subsection{Tujuan}

Tujuan dari kajian ini adalah melakukan analisis biofisik lahan di kawasan rawan longsor dan keterkaitannya dengan kualitas tanah dan penggunaan lahan di wilayah pengembangan agribisnis Juhut di Kabupaten Pandeglang.

\section{METODOLOGI}

\subsection{Lokasi Kajian}

Lokasi kajian berada di wilayah yang diindikasikan kawasan rawan longsor di Desa Juhut Kecamatan Tanjung Sari Kabupaten Pandeglang

\subsection{Metoda Pengumpulan Data}

Data data yang dikumpulkan meliputi data primer dan data sekunder. Data sekunder seperti data statistika kabupaten Pandeglang diperoleh dari BPS Kabupaten Pandeglang, RTRW Kabupaten Pandeglang, dan peta peta tematik seperti peta topografi/lereng, peta jenis tanah, peta tutupan lahan (RBI) dan data curah hujan.

Untuk data primer meliputi data pengamatan lapangan kondisi biofisik lahan, sampling tanah untuk mengetahui kondisi kualitas tanah/lahan dengan trase mengikuti kondisi ketinggian lereng dan kondisi tutupan lahan serta jenis tanah. 


\subsection{Metoda Pengolahan Data}

Analisis biofisik lahan dengan pendekatan analisis peta dan hasil ground ceck. Sedangkan analisis kualitas tanah atau lahan dengan berdasarkan hasil laboratorium untuk parameter fisik dan kimia tanah dengan pendekatan kriteria kualitas tanah Pusat Penelitian Tanah (1997). Sedangkan analisis kawasan rawan longsor dengan metoda overlay dan metoda pembobotan dari berbagai faktor yang mempengaruhi longsor seperti kelerengan, tutupan lahan, jenis tanah, dan curah hujan.

\section{HASIL DAN PEMBAHASAN}

\subsection{Jenis Tanah dan Geologi}

Kabupaten Pandeglang ditinjau dari segi geologi memiliki beberapa jenis batuan yang meliputi Alluvium, Undieferentiated (bahan erupsi gunung berapi), Diocena, Piocena Sedimen, Miocena Lemistone dan Mineral Deposit. Sedangkan beberapa jenis tanah yang ada di Kabupaten Pandeglang yaitu Aluvial, Grumosol, Mediteran, dan Latosol. Luas daerah studi yang meliputi Desa/Kelurahan Juhut yang luas totalnya $1.078,5 \mathrm{Ha}$, sebaran tanahnya dominan merupakan tanah Latosol. Untuk mengetahui sifat fisik dan kimia tanah di Juhut juga telah dilakukan analisis laboratorium. Analisis ini untuk mengetahui gambaran kondisi kesuburan tanahnya, mengingat diwilayah studi lahan yang berlereng curam masih dimanfaatkan untuk budidaya pertanian. Aktivitas budidaya pertanian ini dilahan berlereng karena faktor sosial masyarakat juga karena aspek sifat tanahnya yang mendukung untuk usaha budidaya pertanian.

\subsection{Topografi dan Morfologi Lahan}

Keadaan geomorfologi, topografi dan bentuk wilayah secara bersama-sama akan membentuk pola-pola aliran sungi yang ada. Pola aliran sungai di Wilayah Kabupaten Pandeglang pada umumnya berbentuk dendritik. Arah aliran sungai-sungai di Wilayah ini dibedakan menjadi dua, sehingga membentuk dua daerah aliran sungai yaitu daerah aliran dari arah Timur yang bermuara di Selat Sunda dan daerah aliran dari arah Utara yang bermuara di Samudera Indonesia. Topografi atau kelerengan wilayah di Kabupaten Pandeglang bervariasi dari datar hingga bergunung Sementara itu di wilayah Juhut secara fisik morfologis, kelerengan bergelombang hingga berbukit sebagaimana terlihat seperti pada Gambar 1.

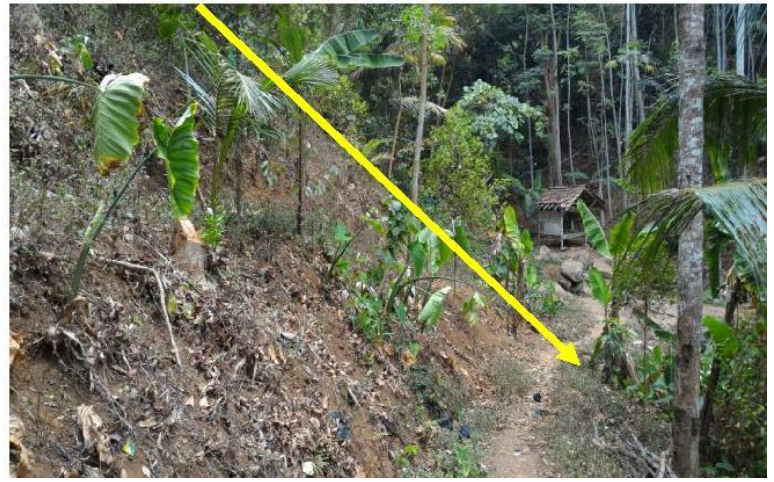

Gambar 1. Kelerengan Lahan di Wilayah Juhut Kabupaten Pandeglang

\subsection{Karakteristik Kualitas Tanah}

Mengingat wilayah Keluruhan Juhut sebagimana diketahui sebagian wilayahnya bergelombang hingga berbukit dan merupakan lereng dari Gunung Karang, secara faktual lahan yang berfisiografi ini juga dimanfaatkan untuk aktivitas budidaya pertanian. Sebagai sentra wilayah agribisnis peternakan dan pertanian, aktivitas budidaya yang ditengarahi mempunyai prospek ekonomi tinggi adalah budidaya

pertanian hortikultura Talas. Untuk bisa menjelaskan bagaimana budidaya Talas ini sebagai bagian aktivitas budidaya yang sangat penting bagai sebagian petani di Kelurahan Juhut, maka juga perlu ditelusuri informasi pendukung tentang karakteritik tanahnya baik sifat fisik dan kimia tanahnya. Meskipun apakah kondisi karakteristisk ini mempunyai korelasi atau tidak dengan potensi bencana longsor namun akivitas budidaya ini juga perlu perlindungan atau bahkan perlu diwaspadai di wilayah yang berpotensi ancaman bencana longsor. Adapun hasil analisis sifat fisik dan kimia tanah diwilayah Juhut yang telah diambil sampling tanahnya terkait kondisi ekologi lahannya adalah seperti disajikan pada Tabel 1 dan analisisnya penjelasannya sebagaimana disajikan pada pembahasan berikut dibawah ini. 
Tabel 1. Sifat Kimia Fisk Tanah di Wilayah Kalurahan Juhut Kabupaten Pandeglang

\begin{tabular}{|c|c|c|c|c|c|c|c|}
\hline \multirow{2}{*}{ No } & \multirow{2}{*}{$\begin{array}{l}\text { Param } \\
\text { eter }\end{array}$} & \multirow{2}{*}{$\begin{array}{l}\mathrm{S} \\
\text { at } \\
\mathrm{u} \\
\mathrm{a} \\
\mathrm{n}\end{array}$} & \multicolumn{5}{|c|}{ Lokasi Sampling } \\
\hline & & & $\begin{array}{c}\text { JHT } \\
-1\end{array}$ & $\begin{array}{c}\mathrm{JHT} \\
-2\end{array}$ & $\begin{array}{c}\text { JHT- } \\
3\end{array}$ & $\begin{array}{c}\text { JHT- } \\
4\end{array}$ & $\begin{array}{c}\text { JHT-5 } \\
15\end{array}$ \\
\hline 1 & $\begin{array}{c}\text { C- } \\
\text { Organik }\end{array}$ & $\%$ & 1,50 & 2,65 & 2,80 & 2,08 & 1,87 \\
\hline 2 & N-Total & $\%$ & 0,14 & 0,22 & 0,20 & 0,18 & 0,15 \\
\hline 3 & $\begin{array}{c}\mathrm{C} / \mathrm{N} \\
\text { Rasio }\end{array}$ & - & $\begin{array}{c}10,5 \\
0\end{array}$ & $\begin{array}{c}11,8 \\
6\end{array}$ & 14,19 & 11,64 & 12,22 \\
\hline 4 & $\begin{array}{l}\mathrm{P} 205 \\
\text { tersedia }\end{array}$ & $\begin{array}{l}\mathrm{pp} \\
\mathrm{m}\end{array}$ & 6,77 & 2,99 & 6,77 & 30,53 & 1,37 \\
\hline 5 & $\begin{array}{c}\mathrm{K} 2 \mathrm{O} \\
\text { tersedia }\end{array}$ & $\begin{array}{l}\mathrm{pp} \\
\mathrm{m}\end{array}$ & 5,32 & $\begin{array}{c}86,8 \\
8\end{array}$ & 5,32 & 42,11 & 55,90 \\
\hline 6 & $\begin{array}{c}\mathrm{P} 205 \\
\text { potensi } \\
\text { al }\end{array}$ & $\begin{array}{l}\mathrm{pp} \\
\mathrm{m}\end{array}$ & $\begin{array}{c}3988 \\
, 76\end{array}$ & $\begin{array}{c}234 \\
78\end{array}$ & $\begin{array}{c}256,7 \\
6\end{array}$ & $\begin{array}{c}2821 \\
60\end{array}$ & 257,27 \\
\hline 7 & $\begin{array}{c}\text { K2O } \\
\text { potensi } \\
\text { al }\end{array}$ & $\begin{array}{l}\mathrm{pp} \\
\mathrm{m}\end{array}$ & $\begin{array}{c}12,4 \\
0\end{array}$ & 3,63 & 8,89 & 22,08 & 0,30 \\
\hline 8 & $\begin{array}{l}\text { Kadar } \\
\text { Air }\end{array}$ & $\%$ & $\begin{array}{c}21,5 \\
9\end{array}$ & $\begin{array}{c}23,0 \\
5\end{array}$ & 22,46 & 22,64 & 24,49 \\
\hline 9 & $\mathrm{pH}$ & & & & & & \\
\hline & $-\mathrm{H} 2 \mathrm{O}$ & & 5,38 & 5,13 & 5,22 & 5,84 & 4,92 \\
\hline & $\begin{array}{c}-\mathrm{KCl} \\
1 \mathrm{M}\end{array}$ & - & 4,14 & 3,98 & 4,16 & 4,22 & 4,04 \\
\hline 10 & $\begin{array}{l}\text { Tekstur } \\
3 \text { Fraksi }\end{array}$ & & & & & & \\
\hline & - Pasir & $\%$ & 11 & 8 & 5 & 10 & 15 \\
\hline & - Debu & $\%$ & 88 & 90 & 93 & 88 & 83 \\
\hline & - Liat & $\%$ & 1 & 2 & 2 & 2 & 2 \\
\hline
\end{tabular}

Sumber : Hasil Analisis Laboratorium tahun 2015

\subsubsection{Sifat Fisik Tanah}

Tekstur tanah merupakan gambaran tingkat kekasartan atau kehalusan bahan mineral yang menyusun tanah. Tekstur tanah di tentukan oleh proporsi tiga jenis partikel tanah,yaitu pasir,debu/endapan lumpur,dan lempung/liat. Pembagian ini berdasarklan ukuran partikel ketiga jenis tanah tersebut. Pasir memiliki ukuran partikel paling besar sedangkan lempung memiliki ukuran partikel paling kecil. Tekstur tanah menunjukkan komposisi partikel penyusun tanah yang dinyatakan sebagai perbandingan proporsi (\%) relatif antara fraksi pasir, fraksi debu dan fraksi liat (Hanafiah, 2008). Pembagian kelas tektur yang banyak dikenal adalah pembagian 12 kelas tekstur menurut USDA. Nama kelas tekstur menggambarkan penyebaran butiran, plastisitas, keteguhan, permeabilitas kemudian pengolahan tanah, kekeringan, penyediaan hara tanah dan produktivitas berkaitan dengan kelas tekstur dalam suatu

wilayah geografis (Anonim, 2012). Tekstur tanah dapat menentukan ssifat-sifat fisik dan kimia serta mineral tanah. Partikel-partikel tanah dapat dibagi atas kelompok-kelompok tertentu berdasarkan ukuran partikel tanpa melihat komposisi kimia, warna, berat, dan sifat lainnya.

Tekstur tanah dibagi menjadi 12 kelas seperti yang tertera pada diagram segitiga tekstur tanah USDA yang meliputi pasir, pasir berlempung, lempung berpasir, lempung, lempung liat berpasir, lempung liat berdebu, lempung berliat, lempung berdebu, debu, liat berpasir, liat berdebu, dan liat (Lal, 1979). Tanah terdiri dari butir-butir pasir, debu, dan liat sehingga tanah dikelompokkan kedalam beberapa macam kelas tekstur, diantaranya kasar, agak kasar, sedang, agak halus, dan hancur (Hardjowigeno, 1995).

Tekstur tanah sangat menentukan kualitas tanah terutama dalam dalam hal kemampuannya menahan air. Tekstur tanah yang mengandung banyak lempung dianggap memiliki tingkat

kesuburan yang tinggi. Hasil analisis laboratorium tanah di wilayah Juhut, tekstur tanah dengan terdiri tingkat kandungan debu tanah antara $83-93 \%$, jauh lebih dominan dibandingkan dengan fraksi pasir dan liatnya. Fraksi pasir antara $5-15 \%$, sedangkan liatnya antara $1-2 \%$. Berdasarkan pendekatan segitiga tekstur, tanah tanah di Juhut mempunyai kelas tekstur Lempung Berdebu.

\subsubsection{Sifat Kimia Tanah}

\section{- Reaksi Tanah (pH)}

Reaksi tanah menunjukkan sifat kemasaman atau alkalinitas tanah yang dinyatakan dengan nilai $\mathrm{pH}$. Nilai $\mathrm{pH}$ menunjukkan banyaknya konsentrasi ion hidrogen $\left(\mathrm{H}^{+}\right)$di dalam tanah. Makin tinggi kadar ion $\mathrm{H}^{+}$di dalam tanah, semakin masam tanah tersebut. Nilai $\mathrm{pH}$ tanah di lokasi studi berkisar antara $\mathrm{pH} 4.92$ hingga yang tertingi 5.84. Nilai $\mathrm{pH}$ secara umum dibawah $\mathrm{pH}$ 7 , kondisi ini berdasarkan kriteria kualitas tanah dari Pusat Penelitian Tanah tergolong tanah masam.

\section{- Carbon (C) Organik}

Carbon organik tanah menunjukkan kadar bahan organik yang terkandung dalam tanah. 
Bahan organik merupakan sumber $\mathrm{N}$ yang utama di dalam tanah dan berperan cukup besar dalam proses perbaikan sifat fisika, kimia dan biologi tanah. Bahan organik dapat berupa bentuk yang halus dan yang berbentuk kasar. Bahan organik halus mempunyai kadar $\mathrm{N}$ tinggi dengan $\mathrm{C} / \mathrm{N}$ rendah, sedangkan bahan organik kasar mempunyai $\mathrm{N}$ rendah dengan $\mathrm{C} / \mathrm{N}$ tinggi. Kadar C organik tanah di wilayah kajian bervariasi antara $1.5 \%$ hingga $2.8 \%$, namun secara umum kadar C organik tanah masih tergolong baik berkisar sekitar batas kelas sedang.

\section{- Nitrogen Tanah}

Nitrogen tanah merupakan unsur esensial bagi tanaman selain Kaliun dan Phosphat. Bahan organik merupakan sumber $\mathrm{N}$ utama di dalam tanah. Kadar $\mathrm{N}$ tanah biasanya sebagai indikator utama untuk menentukan dosis pemupukan Nitrogen/Urea. Fungsi $\mathrm{N}$ adalah memperbaiki pertumbuhan vegetatif tanaman. Kadar $\mathrm{N}$ tanah di wilayah Juhut Kabupaten Pandeglang bervariasi antara $0.14 \%$ hingga 0.22

$\%$. Dari grafis kadar $\mathrm{N}$ tanah, secara umum lahan mempunyai kadar $\mathrm{N}$ tanah berkisar batas sedang artinya tanah mempunyai ketersediaan yanag cukup dalam mendukung ketersediaan Nitogen tanah untuk pertumbuhan tanaman.

\section{- $\mathrm{P}_{2} \mathrm{O}_{5}$ Tanah}

Unsur $\mathrm{P}$ sangat penting bagi tanaman setelah unsur $\mathrm{N}$ yaitu berfungsi untuk pembentukan bunga, buah dan biji, dan mempercepat pematangan dan memperkuat batang tidak mudah roboh. Dari hasil analisis laboratorium terhadap kadar $\mathrm{P}$ tanah dalam bentuk $\mathrm{P}_{2} \mathrm{O}_{5}$ tanah di wilayah Juhut Kabupaten Pandeglang sangat bervariasi yaitu antara $0.14 \mathrm{mg} / 100 \mathrm{~g}$ hingga $3.05 \mathrm{mg} / 100 \mathrm{~g}$. Nilai kadar $\mathrm{P}_{2} \mathrm{O}_{5}$ ini berdasarkan kriteria penilaian sifat kimia tanah tergolong sangat rendah. Sumber-sumber unsur $P$ berasal dari mineral-mineral yang terdapat dalam tanah itu sendiri.

\section{- $\mathrm{K}_{2} \mathrm{O}$ tanah}

Kadar Kalium dalam bentuk $\mathrm{K}_{2} \mathrm{O}$ merupakan Kalium yang dapat dipertukarkan untuk dapat diserap tanaman. Kadar $\mathrm{K}_{2} \mathrm{O}$ tanah diwilayah studi antara $0.53 \mathrm{mg} / 100 \mathrm{~g}$ hingga $8.69 \mathrm{mg} / 100 \mathrm{~g}$. Kandungan $\mathrm{K}_{2} \mathrm{O}$ ini berdasarkan kriteria kesuburan tergolong rendah hingga sangat rendah. Variasi kandungan $\mathrm{K}_{2} \mathrm{O}_{5}$ tanah ini ditentukan oleh kondisi pembentukan tanahnya.

\subsection{Kondisi Tutupan Lahan dan Penggunaan Lahan}

Berdasarkan peta RTRW Kabupaten Pandeglang tahun 2011-2031, tata guna lahan di wilayah Kabupaten Pandeglang yaitu hutan, hutan rawa, kebun perkebunan, tegalan,/ladang sawah irigasi, sawah tadah hujan, rawa, permukiman. Sementara itu lebih spesifik di wilayah Kalurahan Juhut, penggunaan lahan di wilayah ini terdiri dari permukiman, kebun campuran, sawah tadah hujan dan tegalan. Pada daerah yang berlereng curam penggunaan lahannya bervariasi antara tegalan /ladang dan kebun campuiran. Profil biofisik penggunaan lahan di wilayah studi kelurahan Juhut Kabuapaten Pandeglang sebagaimana terlihat pada Gambar 2 dan Gambar 3.

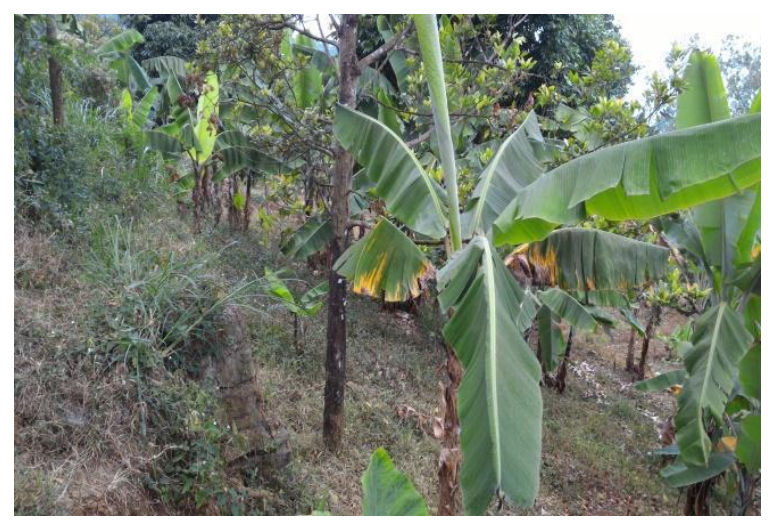

Gambar 2. Penggunaan Lahan Untuk Kebun Campuran dan Tegalan di Wilayah Keluraha Juhut Kabupaten Pandeglang

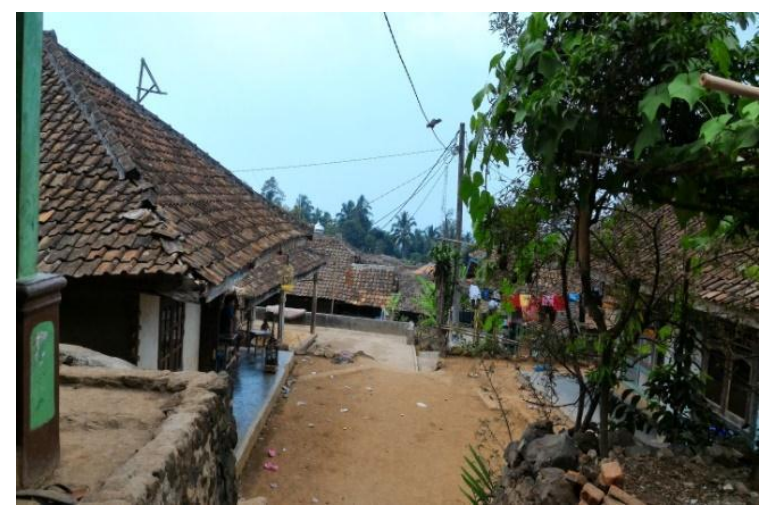

Gambar 3. Permukiman di Wilayah Kalurahan Juhut Kabupaten Pandeglang

\subsection{Kesuburan Tanah dan Aktivitas Budidaya}

Kesuburan tanah adalah kemampuan suatu tanah untuk menyediakan unsur hara, pada takaran dan kesetimbangan tertentu 
secara berkesinambung, untuk menunjang pertumbuhan suatu jenis tanaman pada lingkungan dengan faktor pertumbuhan lainnya dalam keadaan menguntungkan (Poerwowidodo, 1992). Makin tinggi ketersediaan hara, maka tanah tersebut makin subur dan sebaliknya. Kandungan unsur hara dalam tanah selalu berubah ubah, tergantung pada musim, pengolahan tanah dan jenis tanaman (Rosmakam dan Yuwono, 2002). Sementara itu menurut Syarif Effendi (1995), kesuburan tanah adalah suatu keadaan tanah dimana tata air, udara dan unsur hara dalam keadaan cukup seimbang dan tersedia sesuai kebutuhan tanaman, baik fisik, kimia dan biologi tanah.

Tanah yang subur adalah tanah yang mempunyai profil yang dalam (kedalaman yang sangat dalam melebihi $150 \mathrm{~cm}$ ) ; strukturnya gembur ; pH 6,0 - 6,5; kandungan unsur haranya yang tersedia bagi tanaman adalah cukup ; dan tidak terdapat faktor pembatas dalam tanah untuk pertumbuhan tanaman (Sutedjo, 2002).

Bidang pertanian khususnya dalam budidaya tanaman, keadaan tanah dan pengelolaan merupakan faktor penting yang akan menentukan pertumbuhan dan hasil tanaman yang diusahakan. Hal ini disebabkan karena tanah merupakan media tumbuh bagi tanaman, sebagai gudang dan pensuplai unsur hara (Hanafiah, 2005). Bagian dari upaya pengelolaan lahan tentunya terkait dengan kondisi kualitas atau kesuburan tanahnya, sehingga apabila pengelolaan lahan yang subur itu berada pada tanah dengan kondisi biofisik dan morfologi yang kurang mendukung maka dapat menyebabkan bencana alam khususnya bencana lahan yaitu longsor. Sesuai dengan Pedoman Umum Budidaya Pertanian pada Lahan Pegunungan yang tercantum dalam Peraturan Menteri Pertanian Nomor : 47/Permentan/OT.140/10/2006 kelompok jenis tanaman berdasarkan persyaratan fisiologis harus memenuhi persyaratan agronomis yang diekspresikan dalam tingkat kesesuaian tanaman bagi berbagai karakteristik fisik dan kimia tanah. Jenis-jenis tanaman ini yang akan ditanam pada bidang olah lahan berlereng yang telah diteras dan di lahan pekarangan. Lebih lanjut dijelaskan bahwa beberapa jenis tanaman keras mempunyai kesesuaian dan kecocokan terhadap ketinggian tempat terkait pada kondisi agroekosistem lahan pegunungan (Djaenuddin dkk, 2000).

Aktivitas budidaya pada lahan yang diindikasikan rawan bencana longsor di wilayah Juhut terutama pada lahan berlereng > 25\% adalah budidaya tanaman keras berupa kebun campuran, tegalan dan sawah tadah hujan.
Tingkat kerawan lahan berlereng ini diperkuat oleh hasil penelitian Wahyunto (2007) dan Arsyad (2010) yang menyatakan bahwa unsur topografi (kemiringan lereng) yang paling besar pengaruhnya terhadap bencana longsor. Kemiringan lereng sangat berpengaruh terhadap longsor, dimana makin curam lereng, makin besar dan makin cepat longsor terjadi. Sementara itu vegetasi tanaman kebun campuran pada lahan berlereng di wilayah Juhut seperti Pisang, Nangka, Jengkol, Sengon, Pete,

Mangga, Mahoni, Cengkeh. Sedangkan tegalan ditanamani tanaman pangan seperti Jagung, Singkong, Ubi Rambat dan Ubi Talas. Tanaman hortikultura sayuran juga ditanam pada sebagian lahan tegalan. Wilayah Juhut sebagai sentra peternakan berada berada pada lahan yang berlereng curam dan sekitarnya dimanfaatkan untuk budidaya tanaman hortikultura dan tanaman rumput gajah. Aktivitas kegiatan budidaya pada kawasan yang diindikasikan rawa longsor sebagaimana terlihat pada Gambar 4.
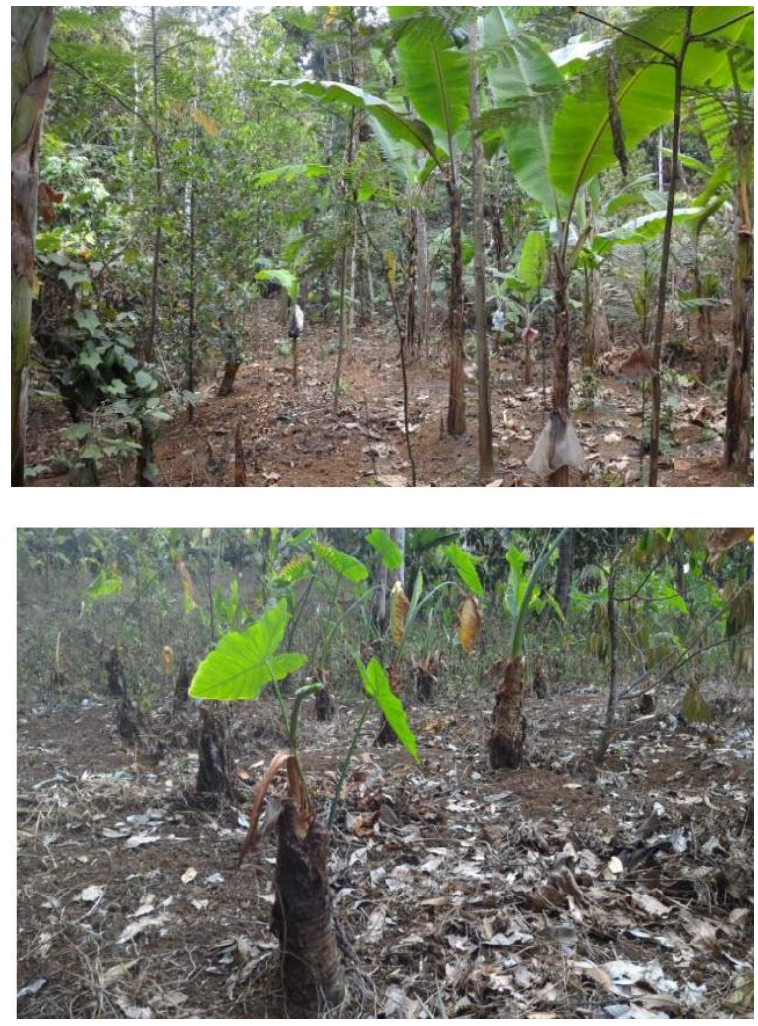

Gambar 4. Budidaya Tanaman Keras/Kebun

Campuran dan Tanaman Pangan Ubi Talas di Juhut Kabupaten Pandeglang

Selain sentra agribisnis peternakan, Juhut juga sangat terkenal dengan budidaya tanaman talas yang mempunyai nilai ekonomi tinggi. Pemanfaatan lahan unrtuk budidaya talas selain 
di ladang atau tegalan juga dibawaha tegakan pohon kebun campuran. Sistem budidaya tanaman yang memanen dengan system mencabut perakaran ini sangat rawan terhadap erosi dan juga bisa menjadi pintu masuk sebagai daerah rawan bencana longsor apabila budidaya tanaman ini dilakukan pada lahan berlereng.

\subsection{Kaitan Kondisi Biofisik Lahan/Kualitas Tanah dan Implikasinya Terhadap Kawasan Rawan Bencana}

Berdasarkan Peta Kawasan Rawan Bencana Kabupaten Pandeglang, wilayah kabupaten Pandeglang mempunyai berbagai potensi rawan bencana seperti bencana gerakan tanah/longsor, bencana banjir, bencana tsunami dan bencana letusan gunung api. Khusus wilayah Juhut Kecamatan Karang Tanjung termasuk rawan bencana alam tanah gerakan tanah dan longsor. Tentunya potensi rawan bencana longsor ini memperhitungan biofisik lahan seperti secara umum Juhut mempunyai kelerengan lebih dari $15 \%$, kondisi tata guna lahan serta kondisi geologi dan tanahnya. Meskipun hingga saat ini wilayah Juhut belum pernah terjadi longsor besar, namun dengan kondisi lereng lebih dari $15 \%$ serta tanah latosol yang mempunyai solum yang dalam, tekstur tanahnya lempung berdebu dan mudah sekali meresepkan air, maka potensi rawan bencana longsor juga cukup tinggi. Keterbukaan lahan atau rendahnya intensitas tutupan lahan oleh vegetasi juga dapat mempengaruhi sifat kemudahan dan kerawanan terhadap longsor. Hal ini apabila terkait dengan struktur tanah yang rapuh dan terkait kondisi sifat fisik mekanis tanah terutama perubahan yang terjadi pada musim kemarau ke musim penghujan. Sifat tanah Latosol yang pada saat musim kemarau mudah sekali mengembang dan menimbulkan rekahan rekahan, apabila musim hujan tiba, maka rekahan tersebut yang berada pada lahan berlereng mudah sekali sebagai pintu masuk aliran air yang akhirnya pada tanah yang berlereng curam akan rawan bencana longsor. Terkait dengan struktur tanah, menurut Syarief (1986), struktur tanah juga mempengaruhi besarnya erosi dan longsor, tanah-tanah yang berstruktur granuler akan menyerap air lebih cepat daripada tanah yang berstruktur massif.

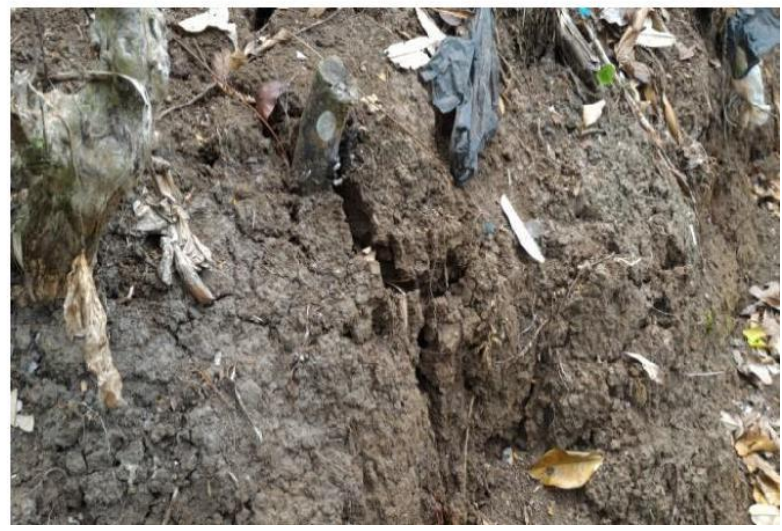

Gambar 5. Jenis Tanah Latosol yang Mempunyai Sifat Mudah Mengembang /Merekah

Lebih lanjut Utomo (1985) menyatakan adanya vegetasi pada lahan membantu pembentukan agregat tanah yang mantap dan menciptakan struktur tanah yang lebih baik sehingga akan menciptakan agregat-agregat yang stabil. Menurut Effendi (2008) struktur tanah dapat menaikkan laju permeabilitas tanah. Semakin banyak ruang antar struktur, maka semakin cepat juga permeabilitas dalam tanah tersebut. Gambaran sifat fisik tanah berupa rekahan tanah Latosol di wilayah Juhut yang pada saat musim hujan bisa menjadi rawan longsor seperti disajikan pada Gambar 5.

\subsection{Zona Kawasan Rawan Longsor}

Analisis detil wilayah Juhut sebagai zona kawasan yang mempunyai potensi rawan longsor didasarkan pada overlay peta tematik kelas lereng, tataguna lahan, jenis tanah (land system) dan curah huja. Hasil analisis tumpang susun berbagai peta tematik tersebut sebagaimana disajikan pada Gambar 6 dengan sebaran kelas bahaya dari rendah hingga tinggi. Wilayah yang mempunyai potensi rawan longsor tinggi berada pada kawasan tengah dan barat laut (wilayah

atas). Apabila ditelusuri dari peta tersebut, daerah yang mempunyai wilayah rawan longsor tinggi berada pada lereng lereng yang mempunyai kecuraman yang tinggi juga (Gambar 7). 


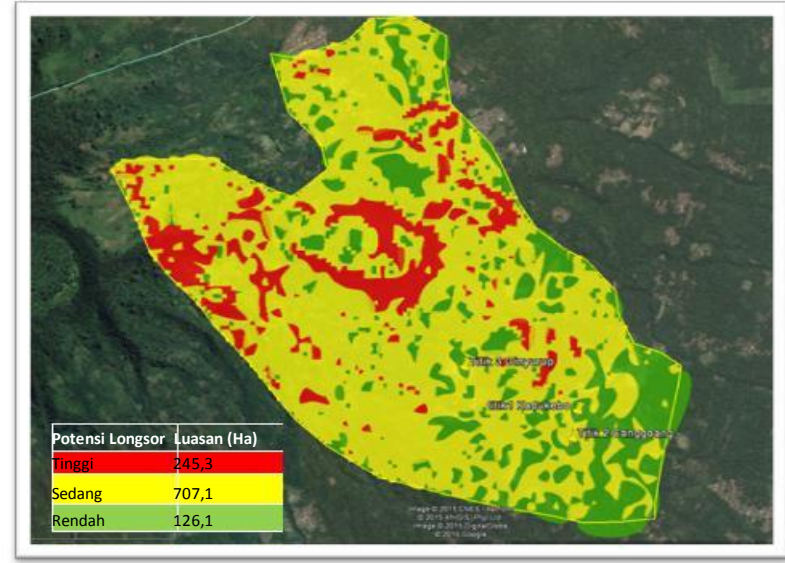

Gambar 6. Potensi Rawan Longsor di Wilayah Juhut

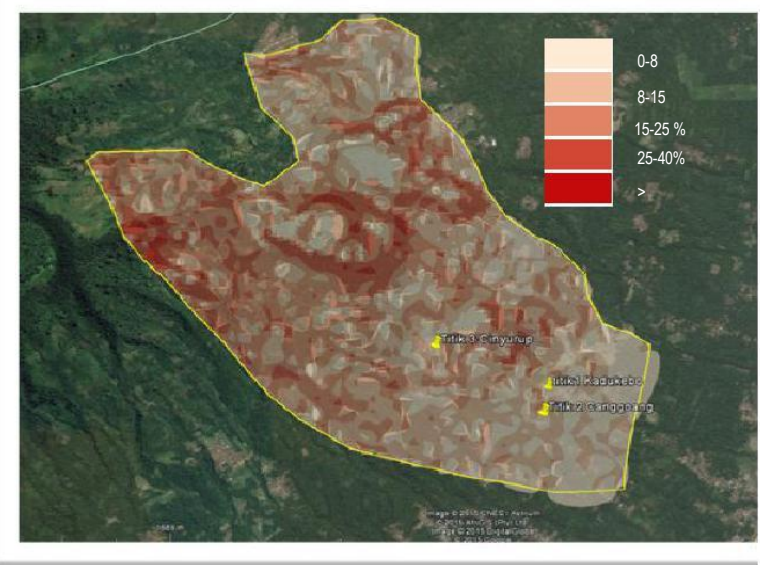

Gambar 7. Kelas Lereng di Wilayah Juhut

Luas potensi longsor tinggi seluas $245 \mathrm{Ha}$, potensi longsor sedang seluas $707.1 \mathrm{Ha}$ sedangkan potensi rendah seluas $126.1 \mathrm{Ha}$. Secara umum terlihat bahwa wilayah Juhut mempunyai potensi longsor sedang dengan prersentasi luasan mencapau hampir $70 \%$ dari luas wilayah yang dikaji. Apabila dilihat dari status tutupan lahan/penggunaan lahan, hasil analisis mosaik citra google earth tahun 2015, kondisi wilayah Juhut mempunyai penggunaan lahan permukiman, hutan, sawah, perkebunan dan lahan terbuka.

Sebagaimana diketahui faktor geologi dan tanah juga berpengaruh besar terhadap kerentanan terhadap potensi bahaya longsor. Tanah tanah dengan solum dalam atau tebal dan dengan sifat struktur dan tekstur mengandung pasiran atau debu tentunya tanah ini akan memudahkan persepan air kedalam tanah. Sementara sifat tanah yang mudah merekah pada saat kemarau, juga menjadi pintu masuk air kedalam tanah pada saat musim hujan. Solum tanah yang tebal, tekstur tanah yang mudah meresapkan air dan terletak pada kondisi lereng yang terjal/miring maka tanah ini juga rentan dan mudah tergelincir. Jenis tanah yang ada di
Juhut secara umum merupakan jenis Tanah Latosol, akan tetapi dari pendekatan peta land system, tanah di Juhut mempunyai land system TGM dan TLU. Land system TGM mempunyai dan berada pada dataran upper slope (mid slopevalley side), sedangkan land system TLU berada diwilayah bawahnya valley side.

Selain faktor geologi dan jenis/karakteristik tanah, vegetasi yang ada dipermukaan tanah juga berpengaruh terhadap terjadinya longsor. Pada tanah tanah dengan solum dalam dengan karakteristik kesuburan yang baik dan berada pada tanah berlereng, vegetasi atau budidaya tanaman merupaka sisi lain yang turut menentukan kerentanan terhadap longsor. Banyak kasus seperti kejadian longsor di Banjarnegara, Pangalengan dan Ponorogo merupakan kawasan budidaya yang subur dikawasan berlereng. Budidaya pertanian yang mengikuti kaidah konservasi tanah, memungkinkan bencana longsor dapat dikurangi. Hasil kajian Soewandita (2013), perpaduan tanaman strata tingi (tanaman keras), tanaman tengah (perdu) dan tanaman semusim merupakan kombinasi terbaik pola budidaya

pertanian dilahan berlereng. Lebih lanjut menurut Sitorus (2006), vegetasi berpengaruh terhadap aliran permukaan, erosi, dan longsor melalui (1) intersepsi hujan oleh tajuk vegetasi/tanaman, (2) batang mengurangi kecepatan aliran permukaan dan kanopi mengurangi kekuatan merusak butir hujan, (3) akar meningkatkan stabilitas struktur tanah dan pergerakan tanah, dan (4) transpirasi mengakibatkan kandungan air tanah berkurang. Keseluruhan hal ini dapat mencegah dan mengurangi terjadinya erosi dan longsor.

\section{KESIMPULAN}

1. Wilayah Juhut merupakan wilayah yang mempunyai kondisi biofisik dan morfologi lahan dari lereng bergelombang hingga berbukit, dengan kondisi tutupan lahan atau penggunaan lahannya dominan kebun campuran dan ladang/tegalan.

2. Tingkat pengelolaan tanah sangat terkait dengan kondisi kesuburan tanah meskipun berada dikawasan berlereng dan digunakan untuk usaha budidaya tanaman baik tanaman keras ataupun tanaman semusim yang berimplikasi terhadap makin tingginya kerentanan terhadap bencana longsor

3. Hasil zonasi wilayah rawan longsor di Juhut menunjukkan sebagian besar mempunyai zona sedang dengan detil perincian zonasi : Zona Longsor tinggi seluas $245.3 \mathrm{Ha}$, Zona longsor sedang seluas $707.1 \mathrm{Ha}$ dan Zona 
4. longsor rendah seluas $126.1 \mathrm{Ha}$. Zona longsor tinggi terutama berada pada wilayah tengah dan wilayah barat laut yang merupakan bagian lereng Gunung Karang.

5. Wilayah zona longsor tinggi berada pada kawasan hutan, akan tetapi dibeberapa lokasi berada pada penggunaan lahan kebun campuran, ladang/tegalan.

6. Upaya pengelolaan lahan zona longsor tinggi pada kawasan budidaya belum menerapkan pola tanam yang sesuai dengan kaidah konservasi lahan.

7. Pola pengelolaan lahan belum sepenuhnya menerapkan konsep konservasi tanah dengan berbasis pada ancaman bahaya longsor.

\section{DAFTAR PUSTAKA}

Arsyad S., 2010. Konservasi Tanah dan Air. IPB Press, Bogor

Djaenuddin, dkk. 2000. Kriteria Kesesuaian Lahan untuk Komoditas Pertanian. Pusat Penelitian Tanah dan Agroklimat. Bogor

Effendi, A. D., 2008. Identifikasi Kejadian Longsor dan Penentuan Faktor - Faktor Utama Penyebabnya di Kecamatan Babakan Madang Kabupaten Bogor. Fakultas Kehutanan Institut Pertanian Bogor. Bogor.

Hanafiah, K.A, 2008. Dasar-Dasar IImu Tanah. PT. Raja Grafindo Persada. Jakarta

Hardjowigeno, S. 1995. IImu Tanah. Akademika Presindo. Jakarta

Lal, R., 1979. Physical Characteristics of Soil of the Tropics : Determination and Management. In : Soil Physical Properties and Crop Production in the Tropics. Edited by : R. Lal and D. J. Greenland, John Wiley \& Sons. New York. Pp 7-44.

Poerwowidodo,1992. Telaah Kesuburan Tanah , Penerbit Angkasa Persada JI. Kronolodong No. 37, Cetakan keempat. Bandung.

Rosmarkam, A. dan N. W. Yuwono. 2002. IImu Kesuburan Tanah. Kanisius, Yogyakarta. Wahyunto, 2007. Kerawanan Longsor Lahan Pertanian di Daerah Aliran Sungai Citarum. Jawa Barat. Balai Penelitian Tanah. Bogor.

Sitorus, S.R. P. 2006. Pengembangan Lahan Berpenutupan Tetap Sebagai Kontrol Terhadap Faktor Resiko Erosi dan Bencana Longsor. Direktorat Jenderal Penataan Ruang Departemen Pekerjaan Umum. Jakarta.

Soewandita, H. 2013. Kajian Kesesuaian Lahan untuk Mitigasi Bencana Lahan di Kawasan Budidaya (Kasus Kawasan Budidaya di Lereng Gunung Sindoro-Sumbing Kabupaten Wonosobo dan Temanggung).
Jurnal Sains dan Teknologi Indonesia Vol. 15. No. 1. 2013 HIm.17-23

Sutedjo. 2005. Analisis Tanah. Gadjah Mada University Press. Yogyakarta

Syarief, S. 1986. IImu Tanah Pertanian. PT. Pustaka Buana. Bandung.

Syarif Effendi, 1995 Ilmu Tanah. Edisi ketiga. PT. Mediyatama Sarana Perkasa.

Utomo, W.H. 1989. Konservasi Tanah di Indonesia. Universitas Brawijaya. Malang.

Wahyunto, 2007. Kerawanan Longsor Lahan Pertanian di Daerah Aliran Sungai Citarum. Jawa Barat. Balai Penelitian Tanah. Bogor.

2006. Peraturan Menteri Pertanian Nomor : 47/Permentan/ OT.140/10/2006 tentang Pedoman Umum Budidaya Pertanian Pada Lahan Pegunungan. Departemen Pertanian. 